\title{
COVID-19 Pandemic in ASEAN Region and Implication in Dentistry
}

\author{
Kanokwan Suttagul ${ }^{1 *}$, Vinai Sirichitra ${ }^{2}$ \\ ${ }^{1}$ Department of Community Dentistry, Faculty of Dentistry, Western University, Lam Luk Ka, Pathumthani, Thailand; ${ }^{2}$ Department \\ of Oral Pathology, Faculty of Dentistry, Western University, Lam Luk Ka, Pathumthani, Thailand
}

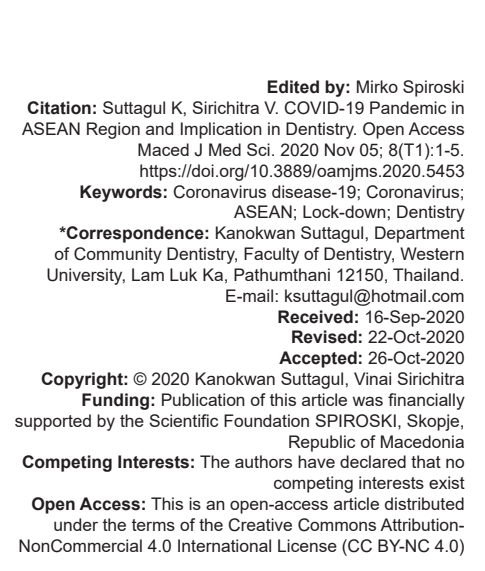

\begin{abstract}
The coronavirus disease (COVID-19) has spread globally and has influenced every aspect of life worldwide. In the ASEAN region, at present, many nations are still locked the academic organizations, shopping malls, events, and activities, and banks and airports are shut down to prevent the spread of the COVID-19 infection. COVID-19 has affected dental practice, and, in many countries, dentists are affected by COVID-19, leading to deaths. The dental treatments should be done with high standards of care and infection control by following proper recommendations. Personal protective equipment, patient screening, hand hygiene practices, mouth rinsing, disposable instruments, and use of rubber dam, reducing ultrasonic instruments use, treating suspected or confirmed COVID-19 patients in separate rooms, and disinfection of the inanimate surfaces helps in protecting clinicians and patients.
\end{abstract}

\section{Introduction}

The coronavirus (CoV) was first seen in Wuhan (China) and it is a form of severe acute respiratory syndrome CoV 2 (SARS-CoV-2) virus [1]. The World Health Organization (WHO) termed it COVID-19 [2]. Then, COVID-19 has spread globally and the WHO declared it pandemic [3], [4], [5]. The global distribution of COVID is shown in Figure 1. Until October 18, 2020, the CoV COVID-19 has affected 210 countries and there have been over 39,959,336 COVID-19 cases with over 1,114,633 deaths [6]. The geographic distribution of 14-day COVID-19 cases worldwide, as of October 17, 2020, is shown in Figure 1 [7]. The outbreak of COVID19 has influenced every aspect of life worldwide. WHO has given details and various aspects of COVID and mentions that currently, there are no specific vaccines or other therapies for COVID-19 [8], [9]. Nevertheless, many ongoing clinical trials are evaluating potential therapies. In addition, no clear evidence of the treatment plan and the prevention and most data in the literature depending on personal experience only which is different from country to others [10].

At present, the COVID-19 outbreak is quick, many nations have locked down the academic organizations, shopping malls, events, and activities, and banks and airports are shut down to prevent its spread. Moreover, people are on self-quarantine to limit the spread of disease [11].

\section{COVID-19 in ASEAN Region}

In ASEAN countries, Singapore and Indonesia show the $1^{\text {st }}$ and $2^{\text {nd }}$ highest number of COVID-19 cases. The total COVID-19 cases in ASEAN countries compared to the USA, Korea, Japan, and China (Table 1).

Table 1: Total COVID-19 cases in ASEAN countries (listed according to the descending order of cases) compared to the USA, Korea, Japan, and China was of July 18, 2020 [6]

\begin{tabular}{lllll}
\hline Countries & Total cases & Total deaths & Total recovered & Active cases \\
\hline Indonesia & 357,762 & 12,431 & 281,592 & 63,739 \\
Philippines & 354,338 & 6603 & 295,312 & 52,432 \\
Singapore & 57,904 & 28 & 57,789 & 9875 \\
Malaysia & 19,627 & 180 & 12,561 & 6886 \\
Myanmar & 34,875 & 838 & 16,370 & 17,667 \\
Thailand & 3686 & 59 & 3481 & 146 \\
Vietnam & 1126 & 35 & 1031 & 60 \\
Cambodia & 283 & - & 280 & 3 \\
Brunei & 147 & 3 & 143 & 1 \\
Laos & 23 & - & 22 & 1 \\
USA & $8,342,665$ & 224,282 & $5,432,192$ & 2,686191 \\
China & 85,672 & 4,634 & 80,786 & 252 \\
Japan & 92,063 & 1661 & 85,030 & 5372 \\
South Korea & 22,504 & 367 & 19,310 & 2827 \\
\hline
\end{tabular}




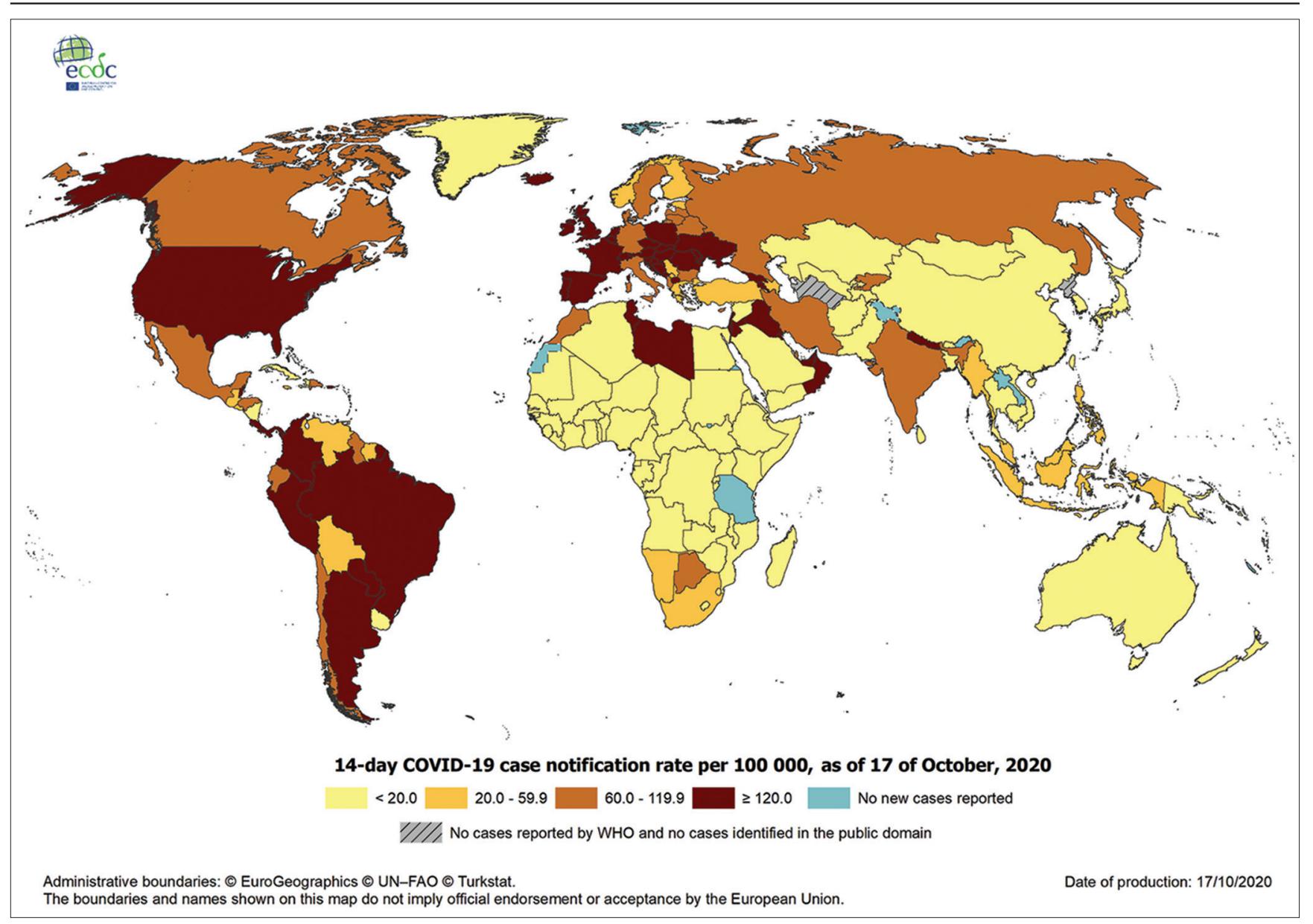

Figure 1: Geographic distribution of 14-day COVID-19 cases worldwide, as of October 17, 2020 [7]

In the ASEAN region, Indonesia and the Philippines show the greatest number of cases. In Indonesia, a total of $10,551 \mathrm{CoV}$ cases were announced until May 1, 2020 [6]. It was found that the number of infections increased during the Ramadan period. There was a ban on Ramadan-related travel, but the government had opposed through the head of the Indonesian COVID-19 taskforce, assuring that people would have to undergo a 14-day quarantine following Ramadan [12]. Singapore shows the third greatest number of COVID-19 cases (57,904 cases) until May 1, 2020 [6]. Singapore is a small and top destination for business meetings and international travelers. In addition, Singapore's Changi airport is one of the most interconnected hubs in the world. At present, the Singapore authorities have increased the health alert and done strict lockdown. Malaysia, Thailand, Cambodia, and Brunei have controlled COVID-19 cases. Recently, more cases are increased in Myanmar and slightly increased in Vietnam. In Thailand, their biggest festival was also banned to prevent the spread of COVID infection. It was found that this festival could increase by 1.3-100 times more infected cases [13]. At present, Thailand has a total of around 3686 cases [6]. Laos has the least cases in the ASEAN region. This may be due to the less population and less travel movement.

\section{Impact of COVID-19 Virus in Dentistry}

As COVID-19 is a respiratory virus, the main clinical manifestations of the infection are fever, fatigue, respiratory symptoms (mainly dry cough), and the emergence of dyspnea. Most infected people show mild to moderate respiratory illness and recover. However, older people with underlying systemic diseases such as diabetes, cardiovascular disease, chronic respiratory disease, and cancer have a higher chance of developing severe illness and may result in mortality [9], [14]. The transmission of the virus can occur through contact with infected people through droplets infection from cough, sneeze, or saliva [15]. Infected people may be asymptomatic may be difficult to diagnose. Clinical diagnosis can be made by the presence of typical ground-glass opacities on chest computed tomography and contact tracing [2], [16].

COVID has an impact on dentists and dental practice. The consequences of anxiety, depression, and stress in people from the outbreak of COVID-19 may lead to temporomandibular disorders (TMD). Hence, the COVID-19 may be correlated with TMD as one of the major causes of TMD is stress and psychosocial impairment [17], [18]. 
In many countries, regular dental treatments are postponed, and only emergency treatment is done. It was found that a high number of dentists, 284 (70\%), were affected by the financial burden and were not receiving a salary during this lockdown [19]. Patients receive dental treatments only from $10 \%$ of the dentists. Only $28(7 \%)$ dentists think they should do the regular dental treatments, but 240 (59\%) dentists think they should do emergency dental treatments for COVID-19 infected cases. It has been shown that some dentists are affected by COVID in Indonesia and Thailand. In Indonesia, 24 medical professionals, including six dentists, have died in the country from COVID-19 [20]. The reason for high COVID cases in medical and dental practitioners may be due to The Indonesian dental association had not advised dentists to close their practices or to postpone nonemergency treatment. After this incident, the Indonesian government has taken seriously on COVID-19 and advised the doctors and dentists to close their practices.

As other health workers, the dentists are at risk of COVID-19 infection due to exposure to hazards such as pathogen exposure, including long working hours, psychological distress, stigma, and fatigue [21]. The treatment component should be strengthened to reduce the case fatality [22]. reach a peak around the end of February of 2020 under the current control measures [15]. But until now, the cases are increasing in many countries in America, Europe, and Asia. Hence, the timing of returning to work should be evaluated carefully, given a different strength of protection and control measures.

The best way of prevention of COVID-19 is well informed about the COVID-19 virus and its transmission. Washing hands or using an alcoholbased rub frequently and not touching our face can prevent its transmission [23]. In Thailand, people have followed social distancing of 1-2 meters in public places such as restaurants, shopping places, public transports, hospitals, elevators, banks, and on a motorbike taxi [Figure 2]. These all helped to reduce the number of new COVID-19 infected cases.

At this time, the academic institutions and schools are closed in ASEAN countries. The academic institutions can implement online lectures for the students for the prevention of COVID transmission [Figure 3]. For the prevention and treatment, the various vaccine is being tested but the efficacy needs to be verified for vaccine development against COVID19 [24].

\section{General Recommendations on COVID Prevention}

Although, the newly confirmed cases would continue to decline and the total confirmed cases will

\section{Recommendations on COVID-19 Prevention in Dentistry}

Oral health is affected in the pandemic and disaster situations similar to the situation of the

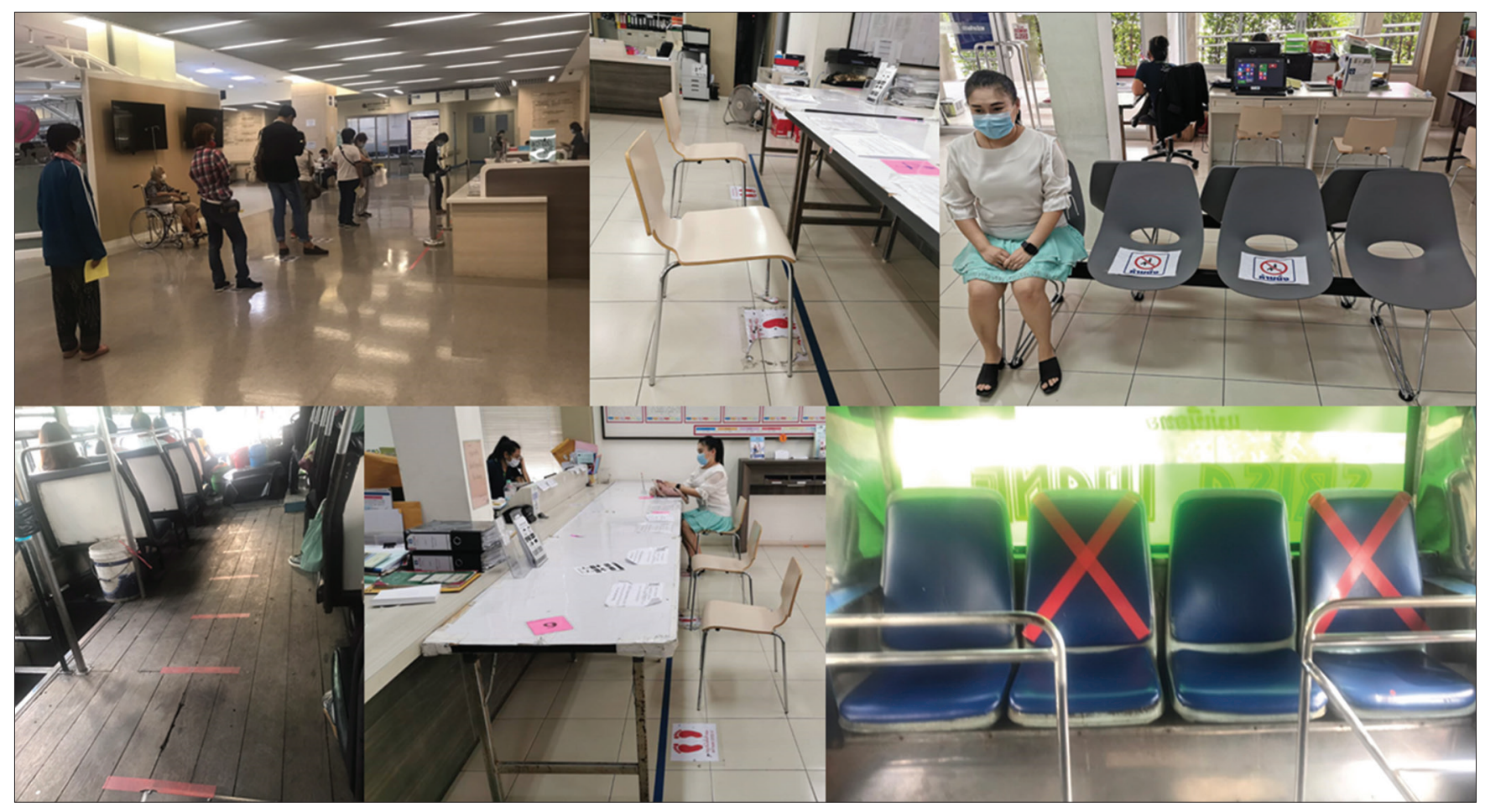

Figure 2: The social distancing of 1-2 meters for COVID prevention in Thailand 
COVID-19 pandemic [25], [26]. Hence, the dentist should manage oral health problems and prevent the spread of COVID-19 in dental practice. Figure 4 shows patient screening flow chat for COVID-19 and dental treatment [23]. A detailed medical history of the patients and their family members should be asked upon their arrival in the dental clinic, such as contact with COVID-19 infected people, history of fever, and travel history in the last 14 days.

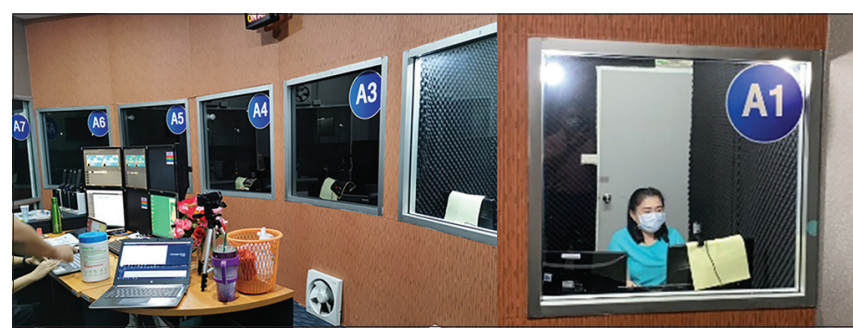

Figure 3: Online delivery of lecture for prevention of COVID

The temperature of the patient must be measured using a non-contact thermometer. The temperature can be measured with a camera having infrared thermal sensors. Patients having a fever $\left(38^{\circ} \mathrm{C}\right.$ or $>100.4^{\circ} \mathrm{F}$ ) and/or symptoms of COVID-19 should be differed in his/her elective dental treatments for $>2$ weeks. The patients with suspected COVID-19 should be kept in a separate and well-ventilated waiting area farther than $6 \mathrm{ft}$ from other people [27]. Patients should be instructed to wear a mask and cover the mouth and nose while coughing or sneezing [28]. After the patient's self-quarantine, they were instructed to contact the physician to rule out the COVID-19.
The dentists may need to manage various dental emergencies in the COVID-19 pandemic period. Emergency dental treatment might be needed for dental trauma and oral infections. The symptomatic irreversible pulpitis is the most common dental emergencies in a COVID-19 period [29]. In emergency cases, vital pulp therapy can be done, reducing treatment time and reducing the risk of further infection. The pharmacologic management (antibiotics and/or analgesics) may be an alternative in COVID-19 infected cases, and the patient can be referred to a suitable place for further treatment afterward. The dental practitioners should be aware of the following things: $\bullet$

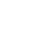

Dental practitioners must follow the guideline from the WHO or CDC, including personal protective equipment (PPE) and hand hygiene [21], [27]. It is advisable to use N95 marks and reuse

- $\quad$ A mouth rinse containing $0.2 \%$ povidone-iodine [30], [31] or $0.5-1 \%$ hydrogen peroxide [32] helps to reduce the CoVs; hence, they can be used before a dental procedure

- Disposable instruments such as mouth mirror, diagnostic probes, and syringes can be used to prevent cross-contamination [23]

- For intraoral radiographs, sensors can be a double barrier to avoid perforation and contamination [33]

- $\quad$ A rubber dam (covers the nose) can be used to minimize splatter generation [29]

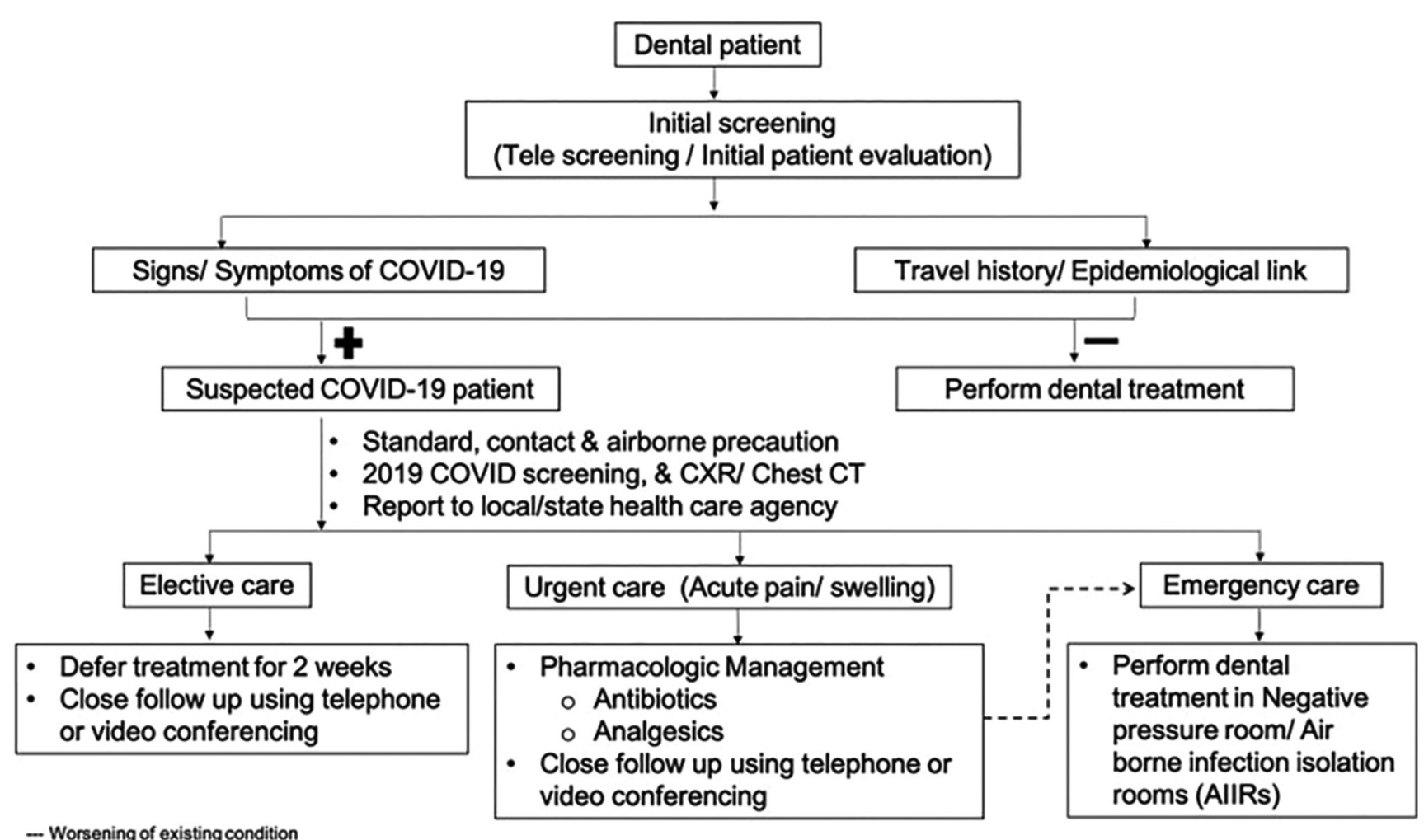

- Worsening of existing condition

Figure 4: Patient screening for COVID and dental treatment [23] 
Reduce the use of ultrasonic instruments, high-speed handpieces, and 3-way syringes to prevent contamination from aerosols [23] The dental treatments of suspected or confirmed COVID-19 patients must be done in separate, airborne infection isolation rooms (AlIRs) or negative-pressure treatment rooms. Good knowledge and positive attitude of health-care staff toward COVID-19 and AllRs can assist dentists in providing dental treatment [34], [35]

SARS CoV-2 is viable in the air for about 3 days [36]. Therefore, the inanimate clinic surfaces must be disinfected using chemicals to prevent its spread.

\section{Conclusions and Recommendations}

In ASEAN countries, Singapore has the maximum number of COVID-19 infections cases followed by Indonesia. The dentist and dental practice are severely affected by the COVID-19 virus. Hence, the timing of returning to work should be evaluated carefully, given a different strength of protection and control measures. Dental professionals have the duty to treat dental treatment protecting the public. The dental procedures should be done with high standards of care and infection control by following proper recommendations. PPE, patient screening, hand hygiene practices, mouth rinsing, disposable instruments, and use of rubber dam, reducing ultrasonic instruments use, treating suspected or confirmed COVID-19 patients in separate rooms, and disinfection of the inanimate surfaces helps in protecting clinicians and patients.

\section{Authors' Contributions}

KS designed the manuscript. KS wrote the manuscript. Both KS and SW contributed to the final version of the manuscript. SW edited the manuscript.

\section{References}

1. Gralinski LE, Menachery VD. Return of the coronavirus: 2019nCoV. Viruses. 2020;12(2):135. https://doi.org/10.3390/v12020135 PMid:31991541

2. Zu ZY, Jiang MD, Xu PP, Chen W, Ni QQ, Lu GM, et al. Coronavirus disease 2019 (COVID-19): A perspective from China. Radiology. 2020;296(2):E15-25.

\section{PMid:32083985}

3. Neher RA, Dyrdak R, Druelle V, Hodcroft EB, Albert J. Potentia impactofseasonalforcing onaSARS-CoV-2pandemic. Swiss Med Wkly.2020;150:w20224.https://doi.org/10.4414/smw.2020.20224 PMid:32176808

4. Khurshid Z, Asiri FY, Al Wadaani H. Human saliva: Non-invasive fluid for detecting novel coronavirus (2019-nCoV). Int J Environ Res Public Health. 2020;17(7):2225. https://doi.org/10.3390/ijerph17072225 PMid:32224986

5. Chakraborty C, SharmaAR, Bhattacharya M, Sharma G, Lee SS The 2019 novel coronavirus disease (COVID-19) pandemic: A zoonotic prospective. Asian Pac J Trop Med. 2020;13(6):242-6.

6. Worldometer. COVID-19 Coronavirus Pandemic. California, USA: Worldometer; 2020.

7. European Centre for Disease Prevention and Control. COVID19 Situation Update Worldwide, as of 17 October 2020. Sweden: Solna Municipality, European Centre for Disease Prevention and Control; 2020.

8. Peng $\mathrm{X}, \mathrm{Xu} \mathrm{X}, \mathrm{Li} \mathrm{Y}$, Cheng L, Zhou X, Ren B. Transmission routes of 2019-nCoV and controls in dental practice. Int J Oral Sci. 2020;12(1):9. https://doi.org/10.1038/s41368-020-0075-9

9. Schwartz D, Addy N, Levine M, Smith H. Oral appliance therapy should be prescribed as a first-line therapy for OSA during the COVID-19 pandemic. J Dent Sleep Med. 2020;7(3):1. https:// doi.org/10.15331/jdsm.7138

10. Tarakji B, Alali FM, Alenzi A, Nassani MZ. Systematic review with no meta-analysis of coronavirus COVID-19. Open Access Maced J Med Sci. 2020;8(T1):108-11.https://doi.org/10.3889/ oamjms.2020.4873

11. Ahmed MA, Jouhar R, Ahmed N, Adnan S, Aftab M, Zafar MS, et al. Fear and practice modifications among dentists to combat novel coronavirus disease (COVID-19) outbreak. Int J Environ Res Public Health. 2020;17(8):2821. https://doi.org/10.3390/ijerph17082821 PMid:32325888

12. Meng L, Hua F, Bian Z. Coronavirus disease 2019 (COVID-19): Emerging and future challenges for dental and oral medicine. J Dent Res. 2020;99(5):4817. PMid:32162995

13. Jitsuk NC, Suttirat $P$, Modchang $C$. Effect of the Songkran festival on COVID-19 transmission in Thailand. Asian Pac J Trop Med. 2020;13(7):331-2. https://doi.org/10.4103/1995-7645.281616

14. Liu K, Chen Y, Lin R, Han K. Clinical features of COVID-19 in elderly patients:Acomparisonwithyoungandmiddle-aged patients. JInfect. 2020;80(6):e14-8. https://doi.org/10.1016/j.jinf.2020.03.005 PMid:32171866

15. Alradhawi M, Shubber N, Sheppard J, Ali Y. Effects of the COVID19 pandemic on mental well-being amongst individuals in society-a letter to the editor on "The socio-economic implications of the coronavirus and COVID-19 pandemic: A review". Int J Surg. 2020;78:147-8. https://doi.org/10.1016/j.ijsu.2020.04.070 PMid:32380230

16. Chang TH, Wu JL, Chang LY. Clinical characteristics and diagnostic challenges of pediatric COVID-19: Asystematic review and meta-analysis. J Formos Med Assoc. 2020;119(5):982-9. PMid:32307322

17. Rokaya D, Koontongkaew S. Can coronavirus disease-19 lead to temporomandibular joint disease? Open Access Maced $\mathrm{J}$ Med Sci. 2020;8(T1):142-3.

18. Almeida-Leite CM, Stuginski-Barbosa J, ContiPC. How psychosocial and economic impacts of COVID-19 pandemic can interfere on bruxism and temporomandibular disorders? J Appl Oral Sci. 2020;28:e20200263. https://doi.org/10.1590/1678-7757-2020-0263 PMid:32401942

19. Humagain M, Humagain R, Rokaya D. An impact of COVID-19 
on dentists, dental practice, and patients in Nepal: A descriptive cross-sectional study. J Nepal Med Assoc. 2020;60(230):764-9.

20. Ghai S. Teledentistry during COVID-19 pandemic. Diabetes Metab Syndr. 2020;14(5):933-5 PMid:32593116

21. Tanaka Y, Almeida FR. What can a dentist and dental sleep apnea researcher do under COVID-19 lockdown? J Clin Sleep Med. 2020;16(9):1641-3. https://doi.org/10.5664/jcsm.8604 PMid:32484777

22. Shrivastava SR, Shrivastava PS. Coronavirus disease 2019 (COVID-19) outbreak: Strengthening the treatment component in health care establishments to minimize case fatality. Asian Pac J Trop Med. 2020;13(5):237-8. https://doi. org/10.4103/1995-7645.281615

23. Ather A, Patel B, Ruparel NB, Diogenes A, Hargreaves KM. Coronavirus disease 19 (COVID-19): Implications for clinical dental care. J Endod. 2020;46(5):58495. https://doi.org/10.1016/j.joen.2020.03.008 PMid:32273156

24. Joob B, Wiwanitkit V. Epitope finding in 2019 novel coronavirus (2019-nCoV): The first world report. Asian Pac J Trop Med. 2020;13:187-8. https://doi.org/10.4103/1995-7645.277515

25. Rokaya D, Suttagul K, Karki S, Rokaya N, Seriwatanachai D, Humagain M. A survey on oral health and practice of Nepalese in areas affected by earthquake in 2015. Kathmandu Univ Med J (KUMJ). 2017;15(57):45-50. https://doi.org/10.3126/kumj.v13i3.16816 PMid:29446362

26. Shrestha U, Rokaya N, Rokaya D, Suttagul K, Shah PK, Humagain M, et al. Post 'Gorkha earthquake' medical problems of the victims in Nepal. J Int Dent Med Res. 2018;11(1):71-5.

27. Basso M, Bordini G, Bianchi F, Prosper L, Testori T, Del Fabbro M. Efficacy of Preprocedural Mouthrinses to Prevent SARS-CoV-2 (COVID-19) transmission: Narrative Literature Review and New Clinical Recommendations. Lombardy, Italy: Quintessenza Edizioni Srl; 2020. p. 10-24.

28. Rokaya D. COVID-19: Prosthodontic challenges and opportunities in dental practice. J Adv Oral Res. 2020;11(2):1-4.

29. Warabi Y, Tobisawa S, Kawazoe T, Murayama A, Norioka R, Morishima $\mathrm{R}$, et al. Effects of oral care on prolonged viral shedding in coronavirus disease 2019 (COVID-19). Spec Care Dent. 2020;40(5):470-4. https://doi.org/10.1111/scd.12498

30. Sabino-Silva R, Jardim AC, Siqueira WL. Coronavirus COVID-19 impactstodentistryandpotentialsalivarydiagnosis. ClinOrallnvestig. 2020;24(4):1619-21. https://doi.org/10.1007/s00784-020-03248-x PMid:32078048

31. Kariwa H, Fujii N, Takashima I. Inactivation of SARS coronavirus by means of povidone-iodine, physical conditions and chemical reagents. Dermatology. 2006;212 Suppl 1(Suppl 1):119-23. https://doi.org/10.1159/000089211 PMid:16490989

32. Kampf G, Todt D, Pfaender S, Steinmann E. Persistence of coronaviruses on inanimate surfaces and their inactivation with biocidal agents. J Hosp Infect. 2020;104(3):24651. https://doi.org/10.1016/j.jhin.2020.01.022 PMid:32035997

33. Hokett SD, Honey JR, Ruiz F, Baisden MK, Hoen MM Assessing the effectiveness of direct digital radiography barrier sheaths and finger cots. J Am Dent Assoc 2000;131(4):463-7. PMid:10770008

34. Jiang X, Deng L, Zhu Y, Ji H, Tao L, Liu L, et al. Psychologica crisis intervention during the outbreak period of new coronavirus pneumonia from experience in Shanghai. Psychiatry Res. 2020;286:112903. https://doi.org/10.1016/j.psychres.2020.112903 PMid:32146245

35. Huynh G, Nguyen TN, Tran VK, Vo KN, Vo VT, Pham LA. Knowledge and attitude toward COVID-19 among healthcare workers at district 2 hospital, Ho Chi Minh City. Asian Pac J Trop Med. 2020;13(6):260-5.

36. Van Doremalen N, Bushmaker T, Morris DH, Holbrook MG Gamble A, Williamson BN, et al. Aerosol and surface stability of SARS-CoV-2 as compared with SARS-CoV-1. N Engl J Med. 2020;382(16):1564-7. https://doi.org/10.1056/nejmc2004973 PMid:32182409 